\title{
PITPNC1 wt Allele
}

National Cancer Institute

\section{Source}

National Cancer Institute. PIT PNC1 wt Allele. NCI Thesaurus. Code C101627.

Human PIT PNC1 wild-type allele is located in the vicinity of 17q24.2 and is approximately $316 \mathrm{~kb}$ in length. This allele, which encodes cytoplasmic phosphatidylinositol transfer protein 1 , is involved in phospholipid transport. 